\title{
The World Bank and Municipal Adjustments in Senegal: Towards a New Institutional Framework
}

\author{
Mebometa Ndongo ${ }^{1} \&$ Juan-Luis Klein ${ }^{2}$ \\ ${ }^{1}$ Institute of African Studies, Carleton University, Ottawa, Canada \\ ${ }^{2}$ Département de Géographie, CRISES, Université du Québec à Montréal, Montréal, Canada \\ Correspondence: Mebometa Ndongo, Institute of African Studies, Carleton University, Ontario, 1125, Colonel By \\ Drive, K1S 5B6, Ottawa, Canada. Tel: 1-514-544-6889. E-mail: mebometa_ndongo@carleton.ca
}

Received: April 16, 2014

Accepted: May 13, 2014

Online Published: May 20, 2014

doi:10.5430/jms.v5n2p82

URL: http://dx.doi.org/10.5430/jms.v5n2p82

\begin{abstract}
This paper adresses the impact of the World Bank's urban development projects on territorial governance in Africa. From the analysis of eight projects completed in Senegal between the 1960s and beyond 2006, the paper identifies the process through which the World Bank adapts systems of actors and local institutional environments to its philosophy of governance. The paper shows that this territorial strategy constitutes a process of municipal adjustment where the local actor contributes to a new focus on governance and where urban development is aligned with globalization.
\end{abstract}

Keywords: local institutional framework, governance, urban development, grafting, Senegal, municipal adjustment

\section{Introduction}

This article examines the governance introduced by the World Bank (hereinafter: the Bank) in Africa, with a particular focus on Senegal through a number of urban development projects. This governance has restructured the local territorial framework to the effect that activities are now organized and implemented according to the development paradigm of the Bank (Tuozzo, 2009). This process, in which local actors are turned into partners, has created favorable conditions for Western-based institution building. By reproducing the Bank's external policies and by implementing development projects designed by the Bank, local actors become stakeholders in the creation of a new institutional framework that is aligned with Western neoliberalism. In that context, it also aligns with what is referred to as New Public Management (Osborne \& Gaebler, 1993; Bezes, 2007), the main goal of which is to bring governments to adopt and internalize the principles and values of the free market (Harvey, 1989).

Within the process of implementing New Public Management, a new local strategy took root consisting of a territorialized version of the Bank's structural adjustment programs (SAPs). Yet, rather than serving the Bank's purported aim of improving citizens' living conditions, this process had the effect of disrupting historically rooted political-administrative structures. This dynamic unfolded across eight urban projects undertaken since 1972, which serve as the empirical basis of our research. A review of factual documents and writings of the Bank associated with these projects allowed us to reconstruct the institutional transformation process and to identify the effects it provoked (Ndongo, 2010).

The first section of the article introduces the main topic of our study and summarizes the criticisms found in the literature of the Bank's development projects. The second section presents the conceptual markers for analyzing the institution-building process engendered by the implementation of World Bank projects. The third section discusses the research methodology. The fourth section shows how municipal adjustment has oriented the new governance established in Senegal at the local level. And the fifth section highlights the developmentalist configuration relied on by the Bank to "graft" a Western form of local governance that will allow it to achieve its goals without socioterritorial and administrative constraints (Bangura, 1994).

Overall, our paper shows that the construction of the new institutionalism was introduced by interventions leading to the destatization and municipalization of governance. It shows how this process transforms the local space and reconfigures the traditional civil, private and community structures of Senegal. We show that even though global actors have the most clout and leverage, local actors are not only victims and gradually become stakeholders in the 
new mode of governance. In fact, what we are seeing is a grafting process, where ideas in favor of globalization intersect with ideas from local elites to create a new institutional setting and a new governance framework. Our hypothesis is that this seemingly progressive transformation, presenting itself as it does as a process of modernization, has negative consequences on the capacity of new governance arrangements to mobilize civil society for the improvement of citizens' living conditions. The grafting of a Western type of local governance onto a traditional governance model destroys the efficiency and operative capacity of the latter. Essentially, a Western type of local governance is remotely programmed and lacks rootedness and social legitimacy at the local level.

The hypothesis of this article is informed by the "new institutionalism," considered to be an effective tool for transforming different domains such as institutions, development and governance (Fuller \& Geddes, 2008) with a multi-sectoral, multi-faceted and multi-scale approach (Brenner \& Theodore, 2002; Narsiah, 2010; Peck \& Tickell, 2002; Weber, 2002; Moulaert \& Nussbaumer, 2008). The type of graft that we favor, drawing on the seminal work of Olivier de Sardan, allows to explicate this hypothesis and to make an original contribution to understanding the implementation of a Western governance model in African countries, where traditional social structures and social hierarchies still have a strong presence at the local level.

\section{Problem: Building a New Local Institutionalism}

In continuation of a previous article in which we analyzed the process of institution building fostered by the World Bank in Senegal (Ndongo \& Klein, 2013), this article addresses the organizational transformation, resulting in a municipal adjustment, introduced by the Bank in Senegal. This transformation is an example of the type of governance brought forth by a new institutional framework grafted by the Bank onto Senegal.

\subsection{The World Bank: Instigator of the Institutional Reconstruction in Africa}

Through a series of programs combining political restructuring, privatization, structural adjustment and capacity building, launched in the 1980 s, the Bank has set up a host of projects aimed at changing the institutional framework in the countries where it operates (Ndongo, 2010; Ndongo \& Klein, 2013). This institution building extends to governance in that it affects the systems of actors as well as the trade-offs between social actors (Boyer \& Saillard, 2002; Jouve, 2003). It affects above all the way in which these actors interact and operate on territories presenting a strong divide between endogenous and exogenous forces, or an unbalanced interaction between local and external forces (Ganesh, 1980). Moreover, the Bank's development activities leading to local institutional transformations subscribe to the mindset propagated by the neoliberalist-capitalist environment in which the Bank has become an influential player (Menéndez, 1991; Zanetta, 2001, 2004; Ramsamy, 2006; Osmont, 1995).

The Bank's strategy is backed by the preferred management ideology of the international donors (Kapur et al., 1997a. 1997b; Zanetta, 2001 2004; Ramsamy, 2006). In our study, we analyze the role of the World Bank in local development in Sub-Saharan Africa from a dynamic perspective developed in 1986 under the new urban management program (Gareth \& Ward, 1994; Wegelin, 1994; Cohen \& Leitmann, 1994) and under the prescriptive angle (of projects) and the local effects of its various interventions. The Bank orients institutions by means of project inputs. In the implementation phase, it plays the role of mentor, maneuvering various local resources and reaching out to the public. Once a project is underway, it controls the outputs in order to maintain its hegemony over its national partners. Whatever form its role takes, one constant emerges: its ability to engage in national government activities and to reorganize state structures (Ramsamy, 2006).

\subsection{Legitimizing the Discourse of the Bank and Its Network of Knowledge}

A number of authors have shown that the Bank essentially subscribes to neoliberalism (Gervais, 1992; Campbell \& Loxley, 1989; Loxley, 1995; Lancaster, 1997; Osmont, 1995), which consolidated at the macro level in the 1980s through the implementation of the SAPs, which had devastating effects for developing countries, especially in Africa. (Note 1)

When examining different studies on SAPs, (Note 2) a pattern emerges: the stripping of the nation state of its capacity for social and economic regulation at the national level. While the first SAPs concentrated on privatization and good governance at the national level, subsequent SAPs gradually began targeting local authorities and civil society as well. In the case of Africa, a World Bank type of governance required, as a precondition, the transformation of the local systems of actors - systems with strongly traditional roots and with values and practices that differ significantly from those promoted by the Bank.

This path, which buttressed the modern municipal actor at the expense of traditional hierarchies, legitimized this option with reference to a "cognitive system" (DiMaggio \& Powell, 1997) that promotes the new values of governance (fight against corruption, accountability, stability, government efficiency, transparency, private property 
and individual entrepreneurship). This cognitive system is the result of knowledge production undertaken by the Bank's staff working from Washington, former Bank's experts working in international institutions and universities, Western researchers working on urban development issues in Africa and local government officials and intellectuals who adhere to, promote and, thereby, legitimize the principles of the New Public Management. Expectedly, this cognitive convergence does exhibit some differences regarding the type of project to be promoted and their implementation. (Note 3) Nevertheless, the differences are overshadowed by the rallying points that, together, impose on the African countries an institutional model informed by globalization but where local actors play an active role (Lindell, 2008; McCarney et al., 1995; Bratton \& Rothchild, 1992; Bratton \& Van de Walle, 1992). The model is essentially comprised of transcalar coalitions of actors who make possible the implementation of local governance systems based on exogenous principles (Bezes, 2007).

The Bank is thus fundamentally involved in the orchestration of institutional configurations and arrangements of actors at the local level that channel the direction of social and economic development. The Bank participates in building a local institutional framework. Aside from its financial role, is also plays an intellectual role that makes its orientations comprehensible and acceptable. It thus positions itself not only as an agent of change in development, but also as an actor who reproduces, propagates and popularizes the approaches and values to be implemented. The Bank's role in urban development in Africa is to intervene in specific institutional contexts, as we shall see in the specific case of Senegal.

\section{Conceptual Framework of the Research}

The type of local institution building introduced by the Bank calls for the adherence to imported standards and values that take precedence over local cultural and territorial identity. In this way, it constitutes an institutional transformation that challenges the actors and disrupts local reality. As a process of neoliberalization, it affects the resources, structures, networks, markets and systems of actors. It also constitutes a "local neoliberalism" in that it produces institutional forms that mobilize the levers of New Public Management.

The New Public Management (NPM) approach was a key vehicle for the realization of the neoliberal state [...] the approach is characterized, by among others, disaggregation or corporatization of the public sector; private sector management styles; discipline and frugality in resource allocation and use; and an emphasis on outputs $[\ldots]$ the public sector which operates along these principles is virtually indistinguishable from the private sector. Furthermore, the emphasis on economic norms and values suggest that the citizen is reincarnated as homo economicus, and is governed in economic terms. In terms of state institutions therefore, at the local level, financial viability becomes an overdetermining factor. The optimization of profits (surplus) and the minimization of costs, in a phrase, conventional neoclassical economics, informs practice [...] a spatial fix is needed to ensure that the process continues and the system does not fall into crisis $[\ldots]$ as in the private sector where value is generated from labor power, in the sphere of production, in the public sector, a similar process occurs in the sphere of consumption as the poor are used to generate a surplus [...] the NPM is the mechanism through which neoliberalism is articulated at various scales of governance (Narsiah, 2013: 137-138; 143-144).

The introduction of New Public Management in Senegal is part of a historical process ensuing from colonization and decolonization and has no ties to the country's traditional institutional environment. The governance advocated by the Bank therefore remains inconsistent with local expectations. It is only through the cooperation of certain local actors who align themselves with the objectives of the Bank that the operationalization of the new governance model and a new configuration of actors becomes possible. To analyze this process, we use the concept of grafting introduced by Olivier de Sardan (1995).

Conceptualization of grafting involves organizations increasing their store of knowledge by formally acquiring employees, firms, and/or by developing long-term alliances with other organizations that possess information not previously available within the organization (Madhavaram \& McDonald, 2010: 1080-1081).

Grafting, in this context, refers to a way of looking at innovation as a result of cross-breeding, hybridization and institutional syncretism. Using this concept, we analyze the new roles and responsibilities of local and municipal actors. Moreover, it allows us to see that these functions, despite their complexity and intersectoral make-up, allow these actors to adapt their activities by adopting new management principles that generate other forms of territorial governance (Mendes, 2008).

Our understanding of grafting is embedded in a broader framework that encompasses the concepts of local governance (Le Galès, 1993; Jouve, 2003), system of actors (Israël, 1996; Crozier \& Friedberg, 1981) and 
locally-based development (Klein, 1997; Moulaert \& Nussbaumer, 2008; Klein \& Champagne, 2011). These conceptual tools allow to identify three types of actors: the Bank, the State and civil society. In the West, civil society is structured on a sectoral basis (e.g., private sector organizations, community organizations, service organizations, political bodies). But in Africa, because of the weight of traditional institutionalism, the sectoral divisions of civil society are blurred and in many areas nonexistent. Thus, the modification of one pillar of local civil society has impacts on the whole.

\section{Questions, Hypotheses and Methodology}

How has the institution building leading to municipal adjustment taken place? To answer this question, we posit the hypothesis that this construction took shape through the grafting of an organizational, action-based and procedural technology. According to this hypothesis, the reconstruction of a local institutional dynamic in Senegal could not materialize without a local governance that favors competition and that complies with neoliberal culture. Under our hypothesis, the juxtaposition of external and local cultural and technological universes has also allowed for the reconstruction of a coherent institutional architecture that is aligned with the aims of the Bank and of the West with regard to Africa.

To analyze this reconstruction, we examined a body of data, derived from factual material from the World Bank, on eight projects that have marked urban intervention in Senegal over four decades. To validate our findings of that review, we consulted twenty experts. Note that we chose Senegal because it is in this country that the Bank tried its intervention on local governance in Africa. The analyzed projects were designed as pilot phases whose results have given rise to an elaborate strategy for all of Sub-Saharan Africa (Osmont, 1995; Kapur et al., 1997a).

\section{Urban Interventions in Senegal by the World Bank: Inductive Vectors of the New Local Governance}

The eight projects studied in our research were dedicated to the fight against poverty and followed sectoral guidelines with regard to urban development. The reconstitution of the process marked out by these projects allows to examine their institutional effect. We grouped the eight projects into five paradigms according to their priorities: physico-spatial (1972-1981), politico-institutional (1984-1997), productive (1989-1997), municipalization (19972006) and municipal adjustment (in operation since 2006). These priorities are indicative of the trajectory constructed by these projects (see Table 1). In this section, we first present an overview of these five paradigms, followed by a detailed description of the final stage, that of municipal adjustment, and an identification of the bases for the institutional grafting process.

Table 1. The projects of the World Bank in Senegal and their approaches by type of priority

\begin{tabular}{|c|c|c|}
\hline $\begin{array}{l}\text { Paradigm according to type of } \\
\text { priority }\end{array}$ & Projects & Approaches \\
\hline $\begin{array}{l}\text { Physico-spatial } \\
(1972-1981)\end{array}$ & - Sites and Services & - Land development \\
\hline $\begin{array}{l}\text { Politico-institutional (1984- } \\
\text { 1997) }\end{array}$ & $\begin{array}{l}\text { Technical assistance for urban } \\
\text { management and rehabilitation } \\
\text { - Municipal and housing } \\
\text { development }\end{array}$ & - Institution building \\
\hline $\begin{array}{l}\text { Urban productivity (1989- } \\
\text { 1997) }\end{array}$ & $\begin{array}{ll}\text { - } & \text { AGETIP } 1 \\
\text { - } & \text { AGETIP } 2\end{array}$ & $\begin{array}{l}\text { - } \text { Job creation } \\
\text { - } \text { Entrepreneurship } \\
\text { - } \quad \text { Productivity of the SME }\end{array}$ \\
\hline $\begin{array}{l}\text { Municipalization } \\
(1997-2006)\end{array}$ & $\begin{array}{l}\text { - Support to the communes } 1 \\
\text { - Support to the communes } 2\end{array}$ & $\begin{array}{ll}\text { - } & \text { Decentralization and } \\
\text { municipal responsibilization }\end{array}$ \\
\hline $\begin{array}{l}\text { Municipal adjustment } \\
\text { (2006 to now) }\end{array}$ & $\begin{array}{l}\text { - Strengthening and equipping of } \\
\text { local communities }\end{array}$ & $\begin{array}{ll}\text { - } & \text { Local investment } \\
\text { - } & \text { Municipal governance }\end{array}$ \\
\hline
\end{tabular}

Source: Ndongo (2010); Ndongo and Klein (2013). 


\subsection{The Stages of Action of the World Bank towards Municipal Adjustment}

The action of the Bank, the paradigms depending on the type of priority, and the projects implemented and approaches adopted are part of a path that evolved in five stages. The first stage (1972-1981) concerned land. By acting on the ground and providing spatial support for all kinds of actions and activities, the Bank created new conditions for the socio-economic functioning and dynamic. To this end, it targeted the public actor in its strategies for penetrating the local level. The second stage (1984-1997) addressed institutions and ensured that the regulatory framework contributed to a bottom-up process of improving economic achievements at the macroeconomic level. In this way, the municipalities as well as the public and private sectors were targeted. The third stage (1989-1997) focused on local resources. Whether human capital or the socio-economic potential, this stage aimed at supporting the productive areas, including the procedures for the participation of institutions and territorialized structures. Civil society, the private sector and the communities were drawn into a logic of institutional privatization. The fourth stage (1997-2006) established territorial structures, among them municipalities, as the basis of a dynamic that combines endogenous and exogenous frameworks. The fifth stage (2006-present), to be discussed in the following section, is that of municipal adjustment, represented by the municipalities constituting the institutional framework and the territorial level targeted by the project.

\subsection{Municipal Adjustment through Strengthening and Equipping Local Authorities}

The fifth stage of the Bank's action in Senegal embodies the process of institutional reconstruction of the local level through municipal adjustment. The communes is the preferred target for the activities of municipalities and private enterprises. Administrative and operational procedures, mechanisms of interaction and institutional arrangements then give form to this stage launched in 2006 under the title: Local Authorities Development Program.

This program operates in a context marked by decentralization. (Note 4) Municipal space has thereby become a focus of the Bank's action in Senegal. This context sheds light on the emergence of new needs, issues, debates and challenges. The needs concern the appropriate maintenance, existing capital, infrastructure management and the stability of the systems designed to ensure the transition to another type of local governance, particularly in the Dakar region, by local (municipal) structures. The issues raised relate to territorial management and fiscal transfers. Debates arise over the institutional configuration and the addition of other phases. The challenges essentially concern the implementation of the decentralization process. Finally, all this draws attention to studies revealing the rapidity of urbanization and the pressure on existing services and infrastructures, especially conflicts between new modes of action and traditional structures.

As this project is part of an interactive dynamic with regard to preceding configurations, the Bank's action aims to promote and strengthen local governance, rule of law and local development by supporting decentralization and accelerating the realization of basic infrastructures to improve access to services. The goal is to increase human capital and improve both the investment and competitiveness of systems, notably infrastructural systems. For this, the Bank continues to exert influence over the processes at work, leading to conflicts with existing local structures.

These processes are illustrated by a networking on the part of the municipalities with regard to their tasks, roles and responsibilities. Whether concerning investments or the maintenance of municipal facilities, it all takes place within an inter-municipal dynamics. This is the new framework of action that is taking root and in which the capital of Dakar plays a central role. The programming of priorities is combined with the implementation of operational tools. The priorities in question aim at repairing or reconstructing transportation infrastructures.

The Bank approves the adoption of economic criteria, such as the eligibility of municipalities to loans. The population is categorized (involved) based on a method of community participation that aims to improve and increase access to basic social services. Thereby reaching the strata of society who are poor and without steady employment, the municipal system is revitalized, if not transformed. While already remarkable achievement in and of itself, these effects on local governance also spill over onto the national territory in that they affect the socio-economic dynamics of secondary cities. In particular, they transform income and employment systems and contribute to decreasing the urban exodus to Greater Dakar, with significant impact on the urban economy and social community.

The integration of socio-environmental issues in project design influences the population. And this constitutes an important criterion for the selection of municipal sub-projects. In fact, this is what, at the initial project stage, and still driven by previous operations, establishes the multiaxial context that channels social, territorial and municipal action and logics, which explains the redefinition of the corresponding operational tools. The policy of the Bank also redefines the roles and responsibilities of local actors, namely as partners in socio-environmental management. This 
includes several municipal agencies, such the Municipal Development Agency, the Contract Management Agency, the Urban Community of Dakar, the Urban Community of Rufisque and the Environmental Protection Agency.

In addition to the deployment of local actors, the categorization and classification of the sub-projects in question sets the tone for the direction of the social development. Moreover, consistent with the logic and directives of the Bank, it also acts as a driver of the social construction of municipal adjustment in Senegal, introducing new tools and changing the role of actors with a view to cultural Westernization. In addition to municipalities, consultants, NGOs and other actors are trained in assessment procedures and urban management with regard to social and environmental issues. The action plan procedures for assessment and reclassification are integrated into specific manuals. Awareness, information, education and communication campaigns are entrusted to the Municipal Development Agency. All these functions are delegated by the government and universities to the local actors-partners, who assume them without any criticism. The documents are distributed to the cities and other stakeholders (World Bank, 2006: 19).

\subsection{The Bases of Institutional Grafting}

In reference to the priorities marking the trajectory of the impact of the studied projects, the bases of institutional grafting in Senegal for the modernization and localization of governance relate to corresponding targets and actions. These bases are based on the rules, procedures, methods, actors, technologies and structures applicable to the local governance (see Table 2).

Table 2. The bases of institutional grafting according to priority

\begin{tabular}{|c|c|c|}
\hline Priority & Goal & Action \\
\hline Physico-spatial & $\begin{array}{l}\text { - Role of the governmental } \\
\text { actors }\end{array}$ & $\begin{array}{l}\text { - Transformation of the state prerogatives } \\
\text { by the fertilization of the context }\end{array}$ \\
\hline Politico-institutional & $\begin{array}{l}\text { Operational management } \\
\text { measures and mechanisms }\end{array}$ & $\begin{array}{l}\text { - } \\
\text { - } \\
\text { - Local participation }\end{array}$ \\
\hline Urban productivity & $\begin{array}{l}\text { - Local non-government } \\
\text { actors: private, civil and } \\
\text { community } \\
\text { - Functioning mechanisms of } \\
\text { organizations } \\
\text { - Administrative structures: } \\
\text { rules, procedures and } \\
\text { methods }\end{array}$ & $\begin{array}{l}\text { - Promotion of local and private } \\
\text { entrepreneurship } \\
\text { - Institutional privatization, procedures } \\
\text { and resources } \\
\text { - Creation of entrepreneurial structures }\end{array}$ \\
\hline Municipalization & $\begin{array}{l}\text { Municipalities as territorial } \\
\text { structures for local } \\
\text { governance }\end{array}$ & $\begin{array}{l}\text { - Responsibilization and territorialization } \\
\text { processes of local governance and } \\
\text { institutional arrangements }\end{array}$ \\
\hline Municipal Adjustment & $\begin{array}{l}\text { - Standards and procedures of } \\
\text { regulation at the communal } \\
\text { level }\end{array}$ & $\begin{array}{ll}\text { - } & \text { Redefinition of intermunicipal } \\
\text { interactions } \\
\text { - } & \text { Networking of municipalities }\end{array}$ \\
\hline
\end{tabular}

When the Bank launches its urban programs, the first phase of a project establishes the dynamic for dealing with unusual actors, including the private sector. Therefore, the State's method for financing housing targets households rather than the public sector, and the State alone still holds and manages the monopoly of local policies and actions. The institutional map consolidates around one actor, complemented by specialized structures such as parapublic organizations like the Office for Low-Income Housing. Dakar, as capital, and the city of Thies polarize the operations. In terms of local governance, the external actors, namely the Bank, the International Development Association and the United Nations Development Programme, retain a constant presence and create the new rules of the game. Locally, these external actors come up against an institutional framework that includes the government, the Office of Low-Income Housing, the Division of Sites and Services, and the municipal administrations of Dakar and Thies. The preexisting local structures are reconfigured and, in a more formal way, the traditional local actors composed of neighborhood chiefdoms and family, tribal and religious groups are excluded from the dynamic of the 
projects. Nevertheless, these actors remain active in the socio-community dynamics and indirectly adopt the vocabulary and subject themselves to the structuring effect of the external actor.

Unlike the first paradigmatic trend, based on the Sites and Services project, the second one no longer integrates the Office of Low-Income Housing into the institutional framework, although it does include the Ministry of Planning and Cooperation. This reflects the institutional importance of the first project of this phase. Seven governmental and municipal structures assume the management. Five departments, (Note 5) three sectoral agencies and the Urban Community of Dakar are represented. Some twenty local actors are involved, whereas the previous project had only a dozen. However, a strong centralization of decision-making powers prevails in the Dakar and departmental institutions. In organizing actions, the governments ensure the completion of all tasks. The decentralized bodies, such as the Urban Community of Dakar, the Division of Local Authorities and even the State Secretariat for Decentralization, participate in neither the planning, nor the programming of investments, nor in urban and housing policies. The decentralized administrations are under-represented in the Monitoring Committee. Private participation remains undefined. Only private firms were consulted in the context of technical assistance for each component. (Note 6) Local participation remains a priority but is limited to the execution and is highly structured and supervised.

From now on, the new roles of actors crystallize in investment, planning and programming regimes. These roles allow them to act at the national level. Meanwhile, municipal politics is revitalized by the introduction of a road works management office. Delegation to agencies for preparatory and implementation works is part of the mode of governance. Newly implanted, novel institutional arrangements unfold in the mechanisms at work. Self-management becomes paramount during the second project of this paradigm, as does the amplification of the role of the local. The latter becomes more active with regard to the mobilization of financial resources. This materializes through the involvement of many local actors, even if some of them belong to the public sector. Contractual terms are redefined, for example for reimbursement, intermediation and technical aspects. All this is done under the watchful eye of the Bank.

In the midst of these strategic orientations, an institutional environment characterized by the effect of structural adjustments takes root, as seen in all operations of the Bank. However, what is important is the place of the local level, which is expressed by the importance of the role of civil society and community groups, next to the private sector. The horizontal and vertical interaction now takes place through intermediaries, who have become indispensable in the operating mechanisms. The emphasis lies on supporting the local workforce, involving youth, and targeting small and medium-sized businesses, especially industrial firms in domestic construction. In this way, the governance framework is resituated through the redefinition of structures previously removed from the scene. Building on the functioning mechanisms of these structures, the realization of public works, such as construction, in urban areas, the restoration and maintenance of equipment, work organization services and adapted training, as well as supervision and monitoring activities are the basic components that led to the creation of an appropriate structure called "Special Agency."

This agency has a special legal status and a particular mode of operation. It is not subject to the regulations, wage standards or personnel policies of public services. It intervenes in the entire classic project cycle, as did the Bank. The innovation lies in the promotion of local and private entrepreneurship. Centralizing the urban development operations in the new institutional responsibilities, it also affects the selection of consulting firms and the sub-projects to prioritize. We are witnessing the establishment of bases and the solidification of the privatization of institutions, procedures and resources. In the second stage, civil society emerges as strong, especially in regards to socio-institutional activities. It tends towards municipalization. In short, the institutional geography is now based on the pitch of the municipalities, who moreover become the center of gravity in a decentralizing dynamic. Thus begins a strong tendency towards destatization. Mechanisms of devolution and trans-national coverage are implemented, targeting all small municipalities with specific activities for adaptation to their situation.

Specifically, the actors involved are part of the new institutional arrangements. Mayors now come into play to negotiate with the government, the Municipal Development Agency, municipalities, the Association of Mayors of Senegal, the Association of Rural Communities, selected contract management agencies, financial institutions and the private sector (contractors, consultants and the beneficiary population). Despite the presence of an agency to whom the execution has been delegated, coordination problems arise. Situated in the overall local urban environment, the aim is to integrate the country's 76 municipalities in a long-term dynamic on local urban governance where they can establish an intermunicipal network. The results of previous projects are related to projects of the fourth paradigm, as they gradually lead to greater local accountability and to municipal adjustments underlying the last paradigm of the newly grafted local institutionalism. 
The municipal adjustment appears as the localized version of structural adjustment; that is to say, it seeks to implement territorial governance modalities that are consistent with the overall policies of the Bank. The applied activities stem from normative measures that the Bank sets up for urban development in order to channel actions according to different priorities, the whole in a programming context based on the operational learning of approaches and projects.

\section{Discussion: Transfer and Grafting of a Developmentalist Configuration}

The study of the phases of the Bank's urban intervention in Senegal brings to the fore the municipal framework. Rupture, experimentation and modeling characterize this dynamic, reflecting the intentions of municipal adjustment of the Bank. As a result, the municipal adjustment implemented in the last phase is part of the investment, the coordinated interaction targeting the population, the intermunicipal relationships and the coordination of donors. By municipal adjustment, we mean all activities applied by the Bank that lead to the strengthening of local structures as part of a framework of governance and regulation.

In the financing of programs, the Bank has control over its operations, leaving little room for recipient countries. One objective of the Bank's urban development program in Africa is to cover between $60 \%$ to $90 \%$ of program costs. With regard to technical assistance, this role seems essential since it mediates the relationships between Washington, the headquarters of the Bank, and the sites of operationalization. This includes the definition of the management approach, the development of action plans and the environmental management. Conducting audits, establishing monitoring and information systems as well as education on environmental issues represent the operational part (Domicelj, 1988; Bigio \& Dahiya, 2004; Edgar, 2004).

As the role related to finance often corresponds to the infrastructural construction and the provision of urban services, the Bank's objectives are embodied in a series of conditions. These concern the repayment of loans, the criteria for the selection of targets, the choice of actors in the field, and the definition of the interaction of the institutions involved (Domicelj, 1988). All this places the Bank in a strong position to impose the adoption of new practices considered more effective but included in the neoliberal paradigm (Tomlinson, 2002; Cohen, 2007; Bezes, 2007).

The institution building of local governance was at the heart of the dynamic of the Bank's urban development projects in Senegal for four decades. Above all, this construction is guided by objectives conceived by the Bank with reference to environmental normativity. Given that this normativity evolves just as the Bank itself, the trajectory drawn by the dynamic of the studied projects remains independent of a history or a local intentionality, or of colonial landmarks that characterize Sub-Saharan Africa. The national and local actors participate in an experiential learning demanded by the pressure of a knowledge network that legitimized the priorities advocated by the Bank. We are witnessing the construction of a local institutional framework that embodies and makes possible the application of Western neoliberalism to which the Bank adheres.

From there, we define the organizational, procedural and action-based technology as a set of techniques/tactics, mechanisms, strategies and practices that shape the institutions and reconfigure their landscape through the paradigms (physico-spatial, politico-institutional, urban productivity, municipalization and municipal adjustment) and the corresponding actors. These actors act at territorial micro and macro scales in the context of glocalization such that the grafting of every paradigm produces another type of governance.

Of course, from a perspective where the use of local material and resources allows globalization to take place, the play of actors emanating from institutional restructurings is part of this logic of endo/exo confrontation. As for civil society and local stakeholders, highlighted in this article, the global/local duality and the interdependence of these two levels are unquestionable.

The last phase of the trajectory of priorities built by the Bank's urban development projects in Senegal highlights the culmination of the process of building the municipal level. A project called "Local Authorities Development Program" serves to build the municipal adjustment. Therefore, it represents its framework of operationalization. Although municipal adjustment refers to all Bank activities leading to the strengthening of local structures as a framework of governance and regulation, it is essentially associated with the type of local governance introduced by the implementation of its projects since the 1970 s.

The social construction of local governance then appears as a result of which the municipal adjustment is a vector. The project that highlights this reality starting with 2006 in Senegal serves as a laboratory for experimentation. This construction becomes incorporated in the governance institutions that are grafted onto the local territory. Since the governance in question constitutes the platform, the process underlying its footing can be understood through the structures put in place to operationalize the municipal adjustment. By developing this project, the Bank engages in 
410 local investments involving city hall, the markets, bus stations, schools, health centers, roads, sewers and drainage, street lighting, hygiene, sanitation and the environment. The objectives are to ensure the sustainability of the social foundations in a transitional phase towards decentralization. Thus, at the institutional level, the partnership with the Municipal Development Agency will allow to build a community support tool that does not compromise the principles already established. The municipality being the territorial basis, the point is to promote the realization of primary infrastructures in order to develop human capital, eradicate poverty and promote economic growth. Touching moreover a key sector such as transportation, it has influenced the socio-professional mobility and transformed the social configuration of the city.

This project incorporates a component of social and human development. Focused on the municipalities, the project builds a new sustainable basis for stakeholders to acquire the necessary skills for filling the territorial gap with regard to infrastructure. As the project covers the entire country, representing 67 municipalities including Greater Dakar and Greater Rufisque, it allows for the establishment of a transition to a social framework for the spread of a Western and modern form of local governance.

With respect to management, the implementation arrangements concern the territorial actors close to the communities. The Municipal Development Agency remains the key player for the operationalization of decentralization. The level of the municipalities is suitable for experimenting with new approaches. The contract management agency acts as an intercommunal and international liaison. Besides the government, all these structures have a local and localized status, whether with regard to their role in the dynamics of the project or their influence in shaping the social fabric.

These local actors participate in the implementation of an interaction process between the local and global, between internal and external, in a tug of war that is clearly uneven. We systematized the relational schemas that determine the compromises, the cohesion and behaviors. We reconstructed the system of actors with new interaction mechanisms and new operating strategies. We polarized the municipal territorial framework through the creation of other groups, the creation of local networks, and the establishment and categorization of (social) identities, with the aim to induce an institutional change that impacts the social organizations that will have to internalize the norms and values inspired externally.

\section{Conclusion}

The objective of this article was to show that the effects urban development projects of the World Bank in Senegal are identical with those of the municipal adjustment project, and to show how this unfolds on Senegalese territory. The urban development projects constitute a local institutionalism, which we analyze as the last step of an institution-building process seeking to establish a local governance framework in Senegal that is consistent with the modes of action and values that the Bank promotes worldwide. The article thereby showed that the grafting of this modern form of local governance introduced by urban intervention configures a different institutional geography than the prevailing one. In a context of destatization, where the transfer of responsibilities takes place from the state to the local level, multiscalar interactions (vertical) and sectoral/territorial (horizontal) are reflected in the redefinition of priorities, targets and actions according to a new configuration of management and administration structures. Therefore, the functioning of local institutions promotes the abandonment of certain global responsibilities, for the benefit of international institutions and global interests. The implementation of international developmentalist configurations in development that supposedly serve municipal adjustment in Senegal also redefined the territorial system and set-up of actors.

The various projects initiated by the Bank with the participation of the Senegalese government and local actors were accompanied by preconditions affecting the macroeconomic environment, the local taxation systems, the laws and the rules of law, transparency and accountability of local governments, as well as public policy and politics. The absorption by local actors of Western norms and rationality leads to the adherence to these conditions and to the application of new models of knowledge and organization. The grafting culminates in a local appropriation of the developed approaches, to the incorporation of these into the local institutional landscapes, and the adoption by the State of norms associated with the New Public Management model promoted by the Bank. The change produced in Senegal reflects the harmonization of development models imposed by the international development institutions in African countries. The practice of New Public Management in these countries is done with the intention to have a model for reforms in the public sector. While mimetism or imitation have been mediatized by mechanisms of cultural adaptation, administrative grafting was undertaken by the international agencies through urban development projects (Minogue, 2006).

Far more than a simple administrative reform, we are witnessing a transfer of values and regulations between the 
North and the South. What we observe is a transformation structured throughout evolutive and coherent paradigms. Although the transformation has not been programmed in all its details, it imposes itself through the application of paradigms constructed by the international aid agencies, and that are based on their development ideology. By incubating the concepts at work, the local actor contributes to this dynamic by reproducing and applying these concepts. The private sector, civil society and community groups act on the provision of services traditionally devolved to the State. These actors can now initiate and operationalize urban projects. This is what redefines the role of the State.

Another institutional hierarchy takes shape above the one established between the traditional local actors (socio-family and spatial groups; traditional, community and religious associations), but without completely eliminating or replacing them. We are witnessing the birth of a hybrid model between globalization and localization. Following this perspective, we can however affirm the following: "Neoliberalism [...] is playing a part in the reconstruction of extralocal relations, pressures, and disciplines [...] as well as extralocal learning" (Peck \& Tickell, 2002). Even though the public/private duality is at the center of institutional and territorial restructurings, new synergies emerge between communities and associations based on the internal and external values. In sum, the contribution of this article concerns the identification of bases, levers and processes of a hybrid local governance model as an effect of the evolution of the Bank's urban interventions in Senegal (Ndongo \& Klein, 2013). This explains the form of glocal governance introduced: the creation of new actors, the definition of new roles and responsibilities of these, and the formalization of new institutional interactions. The process is still underway and the grafting has still not been completed. However, we already see the existence of an adaptation rather than a development dynamic in which local collectivities are destructuring and setting up an intermediary space of governance where traditional structures are either excluded or reduced to serving as foils.

\section{References}

Abdul Aziz, U. (1990). Strategies for structural adjustment: the experience of Southeast Asia. Paper presented at a seminar held in Kuala Lumpur, Malaysia, June 28-July 1, 1989. Washington DC: International Monetary Fund.

Alexander, M., \& Corti, C. (1993). Argentina's privatization program: experience, issues, and lessons. Washington DC: World Bank. http://dx.doi.org/10.1596/0-8213-2586-8

Asian Productivity Organization. (1993). Structural adjustment of agriculture in Asia and the Pacific: report of an APO seminar, 13th-20th October, 1992, Seoul, Republic of Korea. Tokyo: Asian Productivity Organization.

Bangura, Y. (1994). Economic Restructuring, Coping Strategies and Social Change. Development and Change, 25(4), 785-827. http://dx.doi.org/10.1111/j.1467-7660.1994.tb00536.x

Banque Mondiale. (2006). Republic of Senegal, Local Authorities Development program. Project Appraisal Document $N^{\circ} 34941-\mathrm{SN}$, Water and urban 2, Country department 14, Africa Region, Washington DC.

Batista, J. C. (1992). Debt and adjustment policies in Brazil. Boulder: Westview Press.

Beaudet, P. (2008). Le développement face aux enjeux de la mondialisation. In P. Beaudet, Schafer, J., \& P. A. Haslam (Eds.), Introduction au développement international: approches, acteurs et enjeux (pp. 87-105). Ottawa: Les Presses de l'Université d'Ottawa.

Bezes, P. (2007). Construire des bureaucraties wébériennes à l'ère du New Public Management? Critique international, 2(35), 9-29.

Bigio, A. G., \& Dahiya, B. (2004). Urban environment and infrastructure: Toward livable cities. Directions in Development series. Washington DC: World Bank. http://dx.doi.org/10.1596/0-8213-5796-4

Boyer, R., \& Saillards, Y. (2002). Théorie de la régulation: l'état des savoirs. Paris: La Découverte.

Bratton, M., \& Rothchild, D. (1992). The Institutional Bases of Governance in Africa. In G. Hydén, \& M. Bratton (Eds.), Governance and Politics in Africa (pp. 263-284). Boulder: Lynne Reinner Publishers.

Bratton, M., \& Van De Walle, N. (1992). Towards Governance in Africa: Popular Demands and State Responses. In G. Hydén, \& M. Bratton (Eds.), Governance and Politics in Africa (pp. 27-55). Boulder: Lynne Reinner Publishers.

Brenner, N., \& Theodore, N. (2002). Preface: From the "New Localism" to the Spaces of Neoliberalism. Antipode, 34(3), 341-347. http://dx.doi.org/10.1111/1467-8330.00245

Campbell, B. (1995). L'Ajustement en Afrique: L'expérience de la Côte d'Ivoire. Revue Canadienne des Études Africaines, 2(29), 290-302. 
Campbell, B.K., \& Loxley, J. (1989). Structural adjustment in Africa. Basingstoke [England]: Macmillan Houndmills.

Chachage, S. L., Chachage, M. E., \& Gibbon, P. (1993). Mining and structural adjustment: studies on Zimbabwe and Tanzania. Uppsala Nordiska: Afrikainstitutet.

Cohen, M. A. (1983). Learning by Doing. World Bank Lending for Urban Development, 1972-1982. Washington DC: World Bank.

Cohen, M. A. (2007). Aid, Density, and Urban Form: Anticipating Dakar. Built Environment, 33(2), 145-156. http://dx.doi.org/10.2148/benv.33.2.145

Cohen, M. A., \& Leitmann, J. L. (1994). Will the World Bank's real "new urban policy" please stand up?: Comment on "The World Bank's 'new' urban management programme: Paradigm shift or policy continuity?" by Gareth A. Jones and Peter M. Ward. Habitat International, 18(4), 117-126. http://dx.doi.org/10.1016/0197-3975(94)90021-3

Crozier, M., \& Friedberg, E. (1981). L'acteur et le système: les contraintes de l'action collective. Paris: Seuil.

Cruz, W., \& Repetto, R. (1992). The environmental effects of stabilization and structural adjustment programs: the Philippines case. Washington DC: World Resources Institute.

De Janvry, A. (1994). The political feasibility of adjustment in Ecuador and Venezuela. Paris: Development Centre of the Organisation for Economic Co-operation and Development.

Di Maggio, P. J., \& Powell, W. W. (1997). Le néo-institutionnalisme dans l'analyse des organisations. Politix, 10(40), 113-154. http://dx.doi.org/10.3406/polix.1997.1703

Dohner, R., \& Haggard, S. (1994). The political feasibility of adjustment in the Philippines. Washington DC: OECD Publications and Information Centre.

Domicelj, S. (1988). International assistance in the urban sector. Habitat International, 12(2), 5-25. http://dx.doi.org/10.1016/0197-3975(88)90022-7

Edgar, P. (2004). Untangling "integration" in Urban Development Policy Debates. Urban Forum, 15(1), 1-35. http://dx.doi.org/10.1007/s12132-004-0007-3

European Commission. (2011). The economic adjustment programme for Portugal. Luxembourg: Publications Office of the European Union.

Fuller C., \& Geddes, M. (2008). Urban Governance under Neoliberalism: New Labour and the Restructuring of State-Space. Antipode, 40(2), 252-282. http://dx.doi.org/10.1111/j.1467-8330.2008.00591.x

Ganesh, S.R. (1980). Institution Building for Social and Organizational Change: An appreciation. Organization Studies, 1(3), 209-227. http://dx.doi.org/10.1177/017084068000100301

Gareth A. J., \& Ward, P.M. (1994). The World Bank's 'new' urban management programme: Paradigm shift or policy continuity? Habitat International, 18(3), 33-51. http://dx.doi.org/10.1016/0197-3975(94)90003-5

Gervais, M. (1992). Les Enjeux politiques des ajustements structurels au Niger, 1983-1990. Revue Canadienne des Études Africaines, 26(2), 226-249.

Gervais, M. (1995). Ajustements: Un débat stérile, des résultats tronqués et une conclusion biaisée. Revue Canadienne des Études Africaines, 2(29), 272-277.

Gervais, R. R. (1995). Speculative Ajustement. Revue Canadienne des Études Africaines, 2(29), 318-322.

Godfrey, M. (1986). Kenya to 1990: prospects for growth. New York: Economist Intelligence Unit.

Gosovic, B. (2000). L'hégémonie intellectuelle mondiale et développement. Revue internationale des sciences sociales, 166, 507-518. Paris: Unesco/érès.

Hadjimichael, M. T. (1996). Adjustment for growth: the African experience. Washington DC: International Monetary Fund.

Harvey, D. (1989). From managerialism to entrepreneurialism: the transformation of urban governance in late capitalism. Geografiska Annaler, 71, 3-17. http://dx.doi.org/10.2307/490503

Hutchful, E. (1995). Why Regimes Adjust: The World Bank Ponders Its "Star Pupil”. Revue Canadienne des Études Africaines, 26(2), 303-317. 
Israël, A. (1996). Le développement institutionnel: les organisations à l'épreuve de la spécificité et de la concurrence. Paris: L'Harmattan.

Jouve, B. (2003). La gouvernance urbaine en questions. Paris: Elsevier.

Kanaan, T. H. (1997). The social effects of economic adjustment on Arab countries. Washington DC: International Monetary Fund.

Kapur, D., Lewis, J. P., \& Webb, R. C. (1997a). The World Bank: Its First Half Century, Volume one Perspectives. Washington DC: Brooking Institution Press.

Kapur, D., Lewis, J. P., \& Webb, R. C. (1997b). The World Bank: Its First Half Century, Volume two Perspectives. Washington DC: Brooking Institution Press.

Kierzkowski, H., Okolski, M., \& Wellisz, S. (1993). Stabilization and structural adjustment in Poland. New York: Routledge.

Kirton, C. (1992). Jamaica: debt and poverty. Oxford: Oxfam.

Klein, J-L. (1997). L'espace local à l'heure de la globalisation: la part de la mobilisation sociale. Cahiers de géographie du Québec, 41(114), 367-377. http://dx.doi.org/10.7202/022675ar

Klein, J-L., \& Champagne, C. (2011). Initiatives locales et lutte contre la pauvreté et l'exclusion. Québec: Presses de l'Université du Québec.

Lancaster, C. (1997). The World Bank in Africa since 1980: The Politics of Structural Adjustment Lending. In D. Kapur, Lewis, J. P., \& R. Webb (Eds.), The World Bank: Its First Half Century, Volume two Perspectives (pp. 161-194). Washington DC: Brooking Institution Press.

Le Franc, E. (1994). Consequences of structural adjustment; a review of the Jamaican experience. Kingston Jamaica: Canoe Press.

Le Galès, P. (1993). Politique urbaine et développement local. Paris: L’Harmattan.

Lindell, I. (2008). The Multiple Sites of Urban Governance: Insights from an African City. Urban Studies, 45(9), 1879-1901. http://dx.doi.org/10.1177/0042098008093382

Looney, R. E. (1987). The Jamaican economy in the 1980s: economic decline and structural adjustment. Boulder: Westview Press.

Loxley, J. (1995). A Review of Adjustment in Africa: Reforms, Results, and the Road Ahead. Canadian Journal of African Studies, 2(29), 266-271. http://dx.doi.org/10.2307/485242

Lugalla, J. (1995). Adjustment and poverty in Tanzania. Münster: Lit.

Lundy, P. (1999). Debt and adjustment: social and environmental consequences in Jamaica. Brookfield, Vt. USA: Ashgate.

Madhavaram, S., \& McDonald, R. E. (2010). Knowledge-based sales management strategy and the grafting metaphor: Implications for theory and practice. Industrial Marketing Management, 39, 1078-1087. http://dx.doi.org/10.1016/j.indmarman.2009.12.009

Mahmud, W. (2001). Adjustment and beyond: the reform experience in South Asia: proceedings of the IEA conference held in Dhaka, Bangladesh. New York St.: Martin's Press.

Marysse, S. (1995). Rwanda: appauvrissement et ajustement structurel. Bruxelles: CEDAF.

McCarney, P., M. Halfani, \& Rodriguez, A. (1995). Towards an Understanding of Governance: The Emergence of an Idea and its Implications for Urban Research in Developing Countries. In R. Stren, \& J. Kjellberg Bell (Eds.), Urban Research in the Developing World: perspectives on the cuty, 4 (pp. 91-141). Centre for Urban \& Community Studies: University of Toronto.

Mendes, W. (2008). Implementing Social and Environmental Policies in Cities: The Case of Food Policy in Vancouver, Canada. International Journal of Urban and Regional Research, 32(4), 942-967. http://dx.doi.org/10.1111/j.1468-2427.2008.00814.x

Menéndez, A. (1991). Access to Basic Infrastructure By the Urban Poor. Economic Development Institute Policy, Seminar Report n ${ }^{\circ}$ 28. Washington DC: World Bank. http://dx.doi.org/10.1596/0-8213-1813-6 
Minogue, M. (2006). Appels and oranges: comparing international experiences in regulatory reform. In M. Minogue, \& L. Cariño (Eds.), Regulatory Governance in Developing Countries (pp. 61-81). The SCR Series on Competitions, Regulation and Development. Cheltenham UK: Edward Elgar.

Mlambo, A. S. (1997). The economic structural adjustment programme: the case of Zimbabwe, 1990-1995. Harare: University of Zimbabwe Publications.

Moulaert, F., \& Nussbaumer, J. (2008). Logique sociale du développement territorial. Québec: Presses de l'Université du Québec.

Mupedziswa, R. (1998). Structural adjustment and women informal sector traders in Harare, Zimbabwe. Uppsala: Nordiska Afrikainstitutet.

Narsiah S. (2010). The Neoliberalisation of the Local State in Durban, South Africa. Antipode, 42(2), 374-403. http://dx.doi.org/10.1111/j.1467-8330.2009.00751.x

Narsiah S. (2013). Neoliberalism as spatial fix: An example from South Africa. Geoforum, 45, 136-144. http://dx.doi.org/10.1016/j.geoforum.2012.10.011

Ndongo, M. (2010). L'intervention de la Banque Mondiale et la reconfiguration institutionnelle au niveau local: analyse de huit projets de développement urbain au Sénégal (1972-2006). Thèse de doctorat en études urbaines. Montréal: Université du Québec à Montréal.

Ndongo, M., \& Klein, J-L. (2013). The World Bank and the Building of Local Institutionality in Senegal: A Path toward Municipal Adjustment. Urban Studies Research. http://dx.doi.org/10.1155/2013/301068

Olivier de Sardan, J-P. (1995). Anthropologie et développement : essai en socio-anthropologie du changement social. Paris: Karthala.

Olukoshi, A. O. (1998). The elusive prince of Denmark: structural adjustment and the crisis of governance in Africa. Uppsala: Nordiska Afrikaninstitutet.

Osborne, D., \& Gaebler, T. (1993). Reinventing Government: How the Entrepreneurial Spirit is Transforming the Public Sector. New York: Penguin.

Osmont, A. (1995). La Banque mondiale et les villes: du développement à l'ajustement. Paris: Karthala.

Osmont, A., \& Goldblum, C. (2003). Villes et citadins dans la mondialisation. Paris: Karthala-Gemdev.

Peck, J., \& Tickell, A. (2002). Neoliberalizing Space. Antipode, 34(3), 380-404. http://dx.doi.org/10.1111/1467-8330.00247

Pinto, B. (1993). Transforming state enterprises in Poland: microeconomic evidence on adjustment. Washington DC: World Bank.

Ramsamy, E. (2006). The World Bank and Urban Development. New York: Taylor et Francis Group.

Riddell, B. (1995). The World Bank Speaks to Africa yet Again. Revue Canadienne des Études Africaines, 2(29), 262-265.

Samset, K., \& Haavaldsen, T. (1999). Uncertainty in Development Projects. Revue canadienne d'études du développement, 20(2), 382-401. http://dx.doi.org/10.1080/02255189.1999.9669837

Sanbrook, R. (1995). Bringing Politics Back In? The World Bank and Adjustment in Africa. Revue Canadienne des Études Africaines, 2(29), 278-289.

Sharer, R. L. (1995). Uganda: adjustment with growth, 1987-94. Washington DC.: International Monetary Fund.

Tomlinson, R. (2002). Urban Convergence, International Best Practice Enabling Frameworks and the Policy Process: A South African Case Study. Conference Paper, Brisbane, Australia: International Sociology Association.

Tuozzo, M. F. (2009). World Bank Influence and Institutional Reform in Argentina. Development and Change, 40(3), 467-485. http://dx.doi.org/10.1111/j.1467-7660.2009.01559.x

Weber, R. (2002). Extracting Value from the City: Neoliberalism and Urban Redevelopment. Antipode, 34(3), 519-540. http://dx.doi.org/10.1111/1467-8330.00253

Wegelin E. A. (1994). Everything you always wanted to know about the urban management programme (But were afraid to ask): Comment on “The World Bank's 'new' urban management programme: paradigm shift or policy 
continuity?" by Gareth A. Jones and Peter M. Ward Original Research Article. Habitat International, 18(4), 127-137. http://dx.doi.org/10.1016/0197-3975(94)90022-1

Zanetta, C. (2001). The evolution of the World Bank's urban lending in Latin America: from sites and services to municipal reform and beyond. Habitat International, 25(4), 513-533. http://dx.doi.org/10.1016/S0197-3975(01)00022-4

Zanetta, C. (2004). The Influence of the World Bank on National Housing and Urban Policies: the Case of Mexico and Argentine during the 1990s. Chippenham: Ashgate.

\section{Notes}

Note 1. Structural adjustment programs have been the subject of much criticism and debate. Contributors to this debate are, through the Canadian Journal of African Studies 2(29): B. Riddell: 262-265; J. Loxley: 266-271; M. Gervais: 272-277; R. Sanbrook: 278-289; B. Campbell: 290-302; E. Hutchful: 303-317; R. R. Gervais: 318-322, 1995.

Note 2. We examined the development sectors affected in the case of Asia, Poland, Zimbabwe and Tanzania (Asian Productivity Organization, 1993; Pinto 1993; Chachage et al., 1993; Mupedziswa, 1998). Targeted institutional structures have been discussed in the case of Argentina (Alexander \& Corti, 1993). The analysis of the encountered impacts and the consequences arising was examined for the case of the Philippines, the Arab countries, Brazil, Jamaica, Rwanda, Kenya and Uganda (Cruz \& Repetto, 1992; Kanaan, 1997; Batista, 1992; Kirton, 1992; Le Franc, 1994; Lundy, 1999; Looney, 1987; Olukoshi, 1998; Marysse, 1995; Lugalla, 1995; Godfrey, 1986; Sharer, 1995). The corresponding reactions relate to the case of Poland (Kierzkowski et al., 1993). The mechanisms and strategies at work have been studied in the case of Ecuador, Venezuela, the Philippines, Portugal, South Asia and West Africa, especially Zimbabwe (De Janvry, 1994; Dohner \& Haggard, 1994; European Commission, 2011; Mahmud, 2001; Abdul Aziz, 1990; Hadjimichael, 1996; Mlambo, 1997).

Note 3. When analyzing local and external frameworks of intervention, we discover different options within debates on the following topics: institutional development, the success or failure measured with effectiveness and performance indicators (Israël, 1996; Samset \& Haavaldsen, 1999), learning examined from the contextual angle and on the basis of action (Cohen, 1983), international development regarding alternatives to current approaches (Beaudet, 2008; Osmont \& Goldblum, 2003), and the Bank's hegemony regarding its adherence to neoliberal-capitalist ideologies (Ramsamy, 2006; Zanetta, 2001, 2004; Gosovic, 2000).

Note 4. For a complete description of this project, see: World Bank. 2006. Republic of Senegal, Local Authorities Development Program. Project Appraisal Document No. 34941-SN, Water and Urban 2, Department 14 Country, Africa Region. Washington DC.

Note 5. These are the ministries of Economy and Finance, Planning and Cooperation, Equipment, Interior, and Urban Development and Housing.

Note 6. Among them, there are: EPEVRY (project steering) CEGIR (urban investment programming), OTUI (urban development and housing policy), BCEOM (municipal policy) and LAFERRIERE (transportation policy). 